\title{
SØNDERJYSKE ÅBØGER
}

\author{
UDGIVET AF
}

HISTORISK SAMFUND FOR SØNDERJYLLAND

VED

PETER RR. IVERSEN

KNUD FAN $\varnothing$
G. JAPSEN

DORRIT ANDERSEN

I972

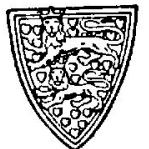


Tryk: Hejmdals Bogtrykkeri

Bogbind: J. P. Møllers Bogbinderi, Haderslev 


\section{NDHOLD :}

Adjunkt Henrik Fangel: Slægten Emmiksen og dens gods ........ side 5- 59

Skoleinspektør Børge L. Barløse: Christianspris - Frederiksort. Fæstningen, som ikke kom til orde .................... - 60 79

Cand. mag. Erik Strange Petersen: *Foreningen af 5. oktober 1898* og den nationale jordkamp i Nordslesvig ............... - 80-146

Arkivar Dorrit Andersen: Rådsbevægelsen i Nordslesvig 1918-20 . . - 147-185

Anmeldelser:

Günter Weitling: Die historischen Voraussetzungen des »Kirchlichen Vereins für Indre Mission in Nordschleswig* und dessen Verbindung zur reichsdänischen Indre Mission bis zur Jahrhundertwende. (Ved

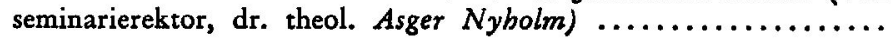
$-186-190$

Wolfgang Prange: Die Anfänge der grossen Agrarreformen in Schleswig-Holstein bis um 1771. (Ved arkivar Viggo Petersen) ....

Gerd. K. Kopper: Zeitungsideologie und Zeitungsgewerbe in der Region. Eine Fallstudie zu den politischen und Strukturbedingungen der Konzentration in Schleswig-Holstein 1945-70. (Ved kandidatstipendiat Anders Ture Lindstrøm) $. . \ldots \ldots \ldots \ldots \ldots \ldots \ldots . . . \ldots \ldots$

Rudolf Asmus og Ericb Maletzke: Das Haus an der Förde. 25 Jahre Schleswig-Holsteinische Landtag 1947-72. (Ved kandidatstipendiat

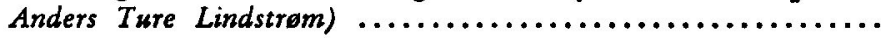

$H$. V. Gregersen: Laurids Skaus brevveksling med politiske venner i Sonderjylland. I-II. (Ved lektor, dr. phil. Jens Engberg) ......

Bognyt: (Ved landsarkivar Peter Kr. Iversen, amanuensis, dr. phil. G. Japsen, socialinspektør Olav Christensen samt arkivar Viggo

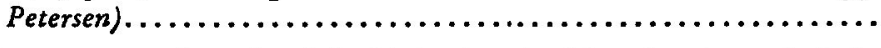

Noter og nyt: Cornelius Schmidt $\dagger$ - Landsarkivet for de sønderjyske landsdele - Historiske samlinger for Sonderjylland - Studieatdelingen ved Dansk Centralbibliotek for Sydslesvig - Haderslev museum Abenră museum - Museet pă Sønderborg slot - Tønder museum Restaureringen af Sønderborg slot - Kunstmuseet "Holmen*, Løgumkloster - Den store egnsvandring 1972 - Amtskredsenes arbejde..

Arsberetning og regnskab 1971-72. (Ved landsarkivar Peter Kr. Iversen og bankdirekør Hugo Lildholt) ...................... - 223-229

Tillag til medlemsfortegnelsen ...................... 230-232 
